\title{
EFFECTS OF BROKEN FAMILY ON PUPILS' BEHAVIORAL DEVELOPMENT AND ACADEMIC SUCCESS
}

\author{
Maria Marquiza A. Felisilda ${ }^{1}$, Leandro C. Torreon ${ }^{2} \square$ \\ ${ }^{1}$ Department of Education- District of Ubay II, Bohol, Philippines \\ 2 Bohol Island State University- Candijay Campus, Cogtong, Candijay, Bohol, Philippines
}

DOI: https://doi.org/10.29121/granthaalayah.v8.i10.2020.1526

Article Type: Research Article

Article Citation: Maria Marquiza A. Felisilda, and Leandro C. Torreon. (2020). EFFECTS OF BROKEN FAMILY ON PUPILS' BEHAVIORAL DEVELOPMENT AND ACADEMIC SUCCESS. International Journal of Research -GRANTHAALAYAH, 8(10), 216-223.

https://doi.org/10.29121/granthaa

layah.v8.i10.2020.1526

Received Date: 11 September 2020

Accepted Date: 31 October 2020

Keywords:

Academic Success

Behavioral Development

Broken Family

Effects

Pupils

\section{ABSTRACT}

Family is the smallest, most sensitive and important social system which is furnished and facilitated by a society as a larger social system. The family, being a powerful influence on the child's development and important primary agent of socialization could in no doubt enhance or hinder the academic achievement of the child depending on the social climate in the family. This study seeks to evaluate the effects of broken family on behavioral development and academic success of pupils in the public elementary school. There were a total of three hundred (300) identified respondents that belonged to broken families that were selected to participate in the study. The researchers used descriptive- survey research method design to probe the pupil's knowledge with regards to the topic, and it employed modified questionnaire (Behavioral Checklist from Psychological Associates, 2019) and direct observation in collecting data from the field. It was found out that age, sex, grade level, number of siblings, and person stays with has no direct influence to the pupils' behavioral development, and however, academic success of the pupils depends on their behavior development. This study concluded that the attitude and behavior of the learner affects their academic success.

\section{INTRODUCTION}

The home influences the child at the most earliest possible time of his life, at a time when his mind is most receptive. It provides the first impression which may last through the whole life of the child. The child often sees the parents, siblings and things in their immediate environment to be most significant and they are capable of promoting or diminishing him in self-worth and academic performance [1].

The family, being a powerful influence on the child and its importance as a primary agent of socialization could in no doubt enhance or hinder the academic achievement of the child depending on the social climate in the family. Variance in psycho-social emotional fortification in the family background could be an indicator to high or low academic performance of students, bearing in mind the intervening effect of high and low socio-economic status and emotional stability of students which is a pre-requisite to academic achievement [2].

When a family breaks up, it is usually difficult for everyone in the family to cope with the situation; however, children are often the worst victims of family breakup. There are powerful reasons to be alarmed about the impact of broken home on children. The stability of family creates a building block for children to progress throughout life.

(C) 2020 The Author(s). This is an open access article distributed under the terms of the Creative Commons Attribution License, which permits unrestricted use, distribution, and reproduction in any medium, provided the original author and source are credited. 
When parents separate, the children are left with no stability causing them to lose basic concepts of childhood and negative perception that may carry with them throughout life.

Broken families may have profound negative impact on student's academic performance as parents play an important role in most children's academic development. Guardians or single parents attributed to limit time that has to spend on their child's academic work [3].

The problem of broken home are universal phenomenal which affect both developed as well as the under develop country. A home is the walls of the house but the people who live on it make a home. A house only becomes a home, when if complete. A home also became a house when is not broken.

It pointed out [4] that the family lays the psychological, moral, and spiritual foundation in the overall development of the child. Structurally, family/homes is either broken or intact. A broken home in this context is one that is not structurally intact, as a result of divorce, separation, death of one of parent and illegitimacy. Psychological home conditions arise mainly from illegitimacy of children [5], the label of adopted child, broken homes, divorce and parental deprivation. Such abnormal conditions of the home, are likely to have a detrimental effect on school performance of the child he asserts.

Life in a single parent family or broken home can be stressful for both the child and the parent. Such families are faced with challenges of inadequate financial resources (children defense find, 2004). As noted [6], in order for self-control to be taught, a parent must be able to monitor their child's behavior, recognize their inappropriate behavior as deviant, and punish them accordingly. The problem for single parent is they may not have the enough time to monitor their child's behavior, and they may not have the means to discipline them. Many single-parent mothers are forced to work long hours and therefore allow their children to do a lot more without any interference. They are also not necessarily aware of their child's misbehavior and their performance in school.

Academic performance is seen as the knowledge attained or skills, shown in the school subject. To indicate such achievement, test scores or marks are assigned by the teachers. It is the school evaluation of the classroom work on the basis of the grades awarded. Academic performance [7] is of two types, the positive and negative (poor) performance. Habits, family background, perseverance, attitudes, interest all these affect academic achievement in school. He concluded that if these variables are modified and attitude changed positively, then the level of individuals' academic performance would improve.

The Abraham Maslow's theory on hierarchy of needs was adopted for this study. It focuses on self-actualization of a person. Some characteristics of a self-actualized person include tolerance, welcoming uncertainty, acceptance of self and other, creativity, need for privacy, autonomy, genuine caring for others, sense of humor and directedness [8]. He divided human needs into five categories. The most basic category is the physiological needs. These include food, shelter, clothing and education. When pupils lack these basic needs, they cannot grow and their concentration is on their discomfort. If pupils are hurt by conflicts in the family, they may not acquire all the needs that they need. After the basic needs, a person yearns for safety needs. This is the need to feel secure. Pupils who witness their parents fighting all the time do not feel safe in that home. There is the fear that the parents might separate or even hurt them.

On other hand, the Attachment Theory [9], child-adult relationships may be secure (close and trusting), resistant (conflicted and/or needy), avoidant (business like and emotionless or over bright) (, or disorganized (a mixture of both patterns of insecurity). The ideal pattern of attachment is conceived as a secure relationship in which a child trusts the adult caregiver to provide consistent, supportive care. Examples of secure attachments can include the following interactions: a child seeks and accepts comfort from the primary caregiver when he/she is upset or hurt, a child shows physical affection toward his/her primary caregiver, a child explores and undertakes new challenges in the company of the caregiver, a child asks for and uses help from the primary caregiver, a child checks in sometimes just visually with the primary caregiver when uncertain, and a child follows directions and suggestions from the primary caregiver [10].

Furthermore, the Family Systems Theory is a theory [11] that suggests that individuals cannot be understood in isolation from one another, but rather as a part of their family, as the family is an emotional unit. Families are systems of interconnected and interdependent individuals, none of whom can be understood in isolation from the system.

Children of broken families generally are more likely to be resource deprived [12], especially in female-headed households [13], and receive less intense and less consistent monitoring, all of which have been associated to mental development and academic success of a child [14]. 
With the aforementioned scenario above, the researcher prompt to conduct this study on the influence of broken home on the behavior and academic performance of students in order to create an action plan to help the pupils/learners find success and overcome unpleasant experiences.

\section{MATERIALS AND METHODS}

\subsection{RESEARCH DESIGN}

This study utilize a descriptive- survey design. Surveys are often part of research designs (usually in the form of a questionnaire) and in this study, a survey is used to probe the pupil's knowledge with regards to the influence of broken families on their mental development and academic success.

\subsection{ENVIRONMENT AND PARTICIPANTS}

The target respondents for the study were the purposively selected elementary pupils of elementary schools in District III of Ubay, Bohol, Philippines who were from broken family during the school year 2019-2020. The location is the biggest municipality in the province of Bohol which composed of 44 barangays and about 150 kilometers away from the capital city of Tagbilaran. The map of Ubay, Bohol, Philippines was presented in figure 1.

There were a total of three hundred (300) identified public elementary school pupils that belonged to broken families in Ubay district broken down as one hundred forty - nine (149) males and one hundred fifty - one (151) females from grade one to seven.

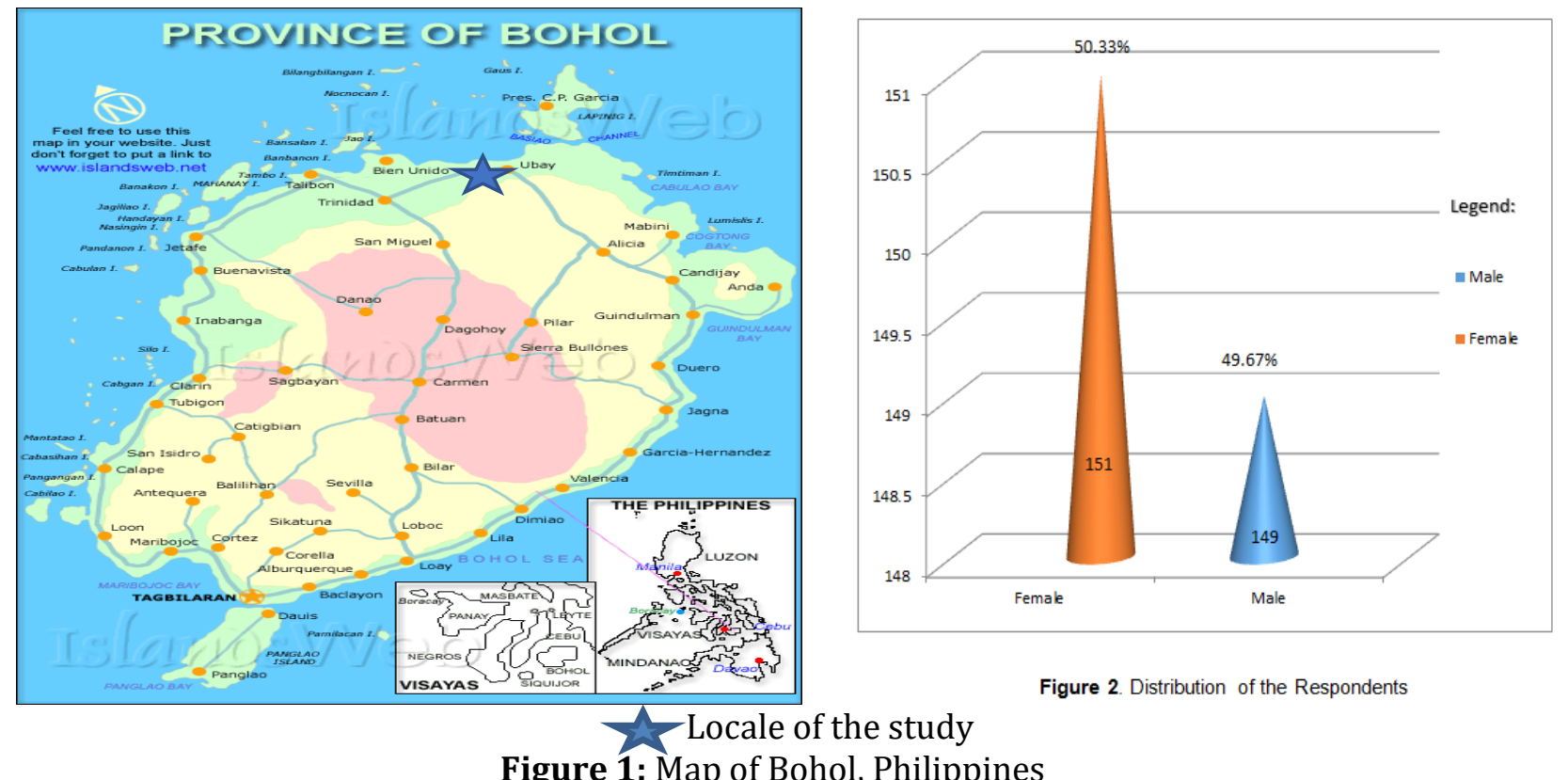

Figure 1: Map of Bohol, Philippines

\subsection{MATERIALS}

This study employed modified questionnaire and direct observation in collecting data from the field. The questionnaires were close ended with alternatives provided for respondents to choose from. Respondents were assisted by the researchers with the help of their class adviser. The said questionnaire was pilot tested in order to validate the content statements and its reliability through the assessment of the statistician.

The results were tabulated, interpreted and discussed as basis in analyzing and interpreting the data. The researchers used percentage, weighted mean, Chi - square test of independence, and Spearman Rank Coefficient Correlation. 


\section{RESULTS AND DISCUSSIONS}

This study seeks to evaluate the effects of broken family on the behavioral development and academic success of pupils in the public elementary school of Ubay, Bohol, Philippines.

\section{Profile of The Respondents}

Table 1: Profile of the Respondents

\begin{tabular}{|c|c|c|c|}
\hline 1.1 Age & Frequency & Percentage (\%) & Rank \\
\hline 6 & 47 & 15.67 & 4 \\
\hline 7 & 39 & 13.00 & 6 \\
\hline 8 & 40 & 13.33 & 5 \\
\hline 9 & 55 & 18.33 & 2 \\
\hline 10 & 48 & 16.00 & 3 \\
\hline 11 above & 71 & 23.67 & 1 \\
\hline Total & 300 & $100 \%$ & \\
\hline \multicolumn{4}{|c|}{$1.2 \mathrm{Sex}$} \\
\hline Male & 149 & 49.67 & 2 \\
\hline Female & 151 & 50.33 & 1 \\
\hline Total & 300 & $100 \%$ & \\
\hline \multicolumn{4}{|c|}{1.3 Grade Level } \\
\hline Grade 1 & 48 & 16.00 & 2 \\
\hline Grade 2 & 45 & 15.00 & 4 \\
\hline Grade 3 & 45 & 15.00 & 4 \\
\hline Grade 4 & 47 & 15.67 & 3 \\
\hline Grade 5 & 45 & 15.00 & 4 \\
\hline Grade 6 & 70 & 23.33 & 1 \\
\hline Total & 300 & $100 \%$ & \\
\hline \multicolumn{4}{|c|}{ 1.4 Number of Siblings } \\
\hline 2 and below & 122 & 40.67 & 1 \\
\hline $3-4$ & 104 & 34.67 & 2 \\
\hline $5-6$ & 41 & 13.67 & 3 \\
\hline $7-8$ & 15 & 5.00 & 4 \\
\hline $9-10$ & 3 & 1.00 & 5 \\
\hline 11 above & 15 & 5.00 & 4 \\
\hline Total & 300 & $100 \%$ & \\
\hline \multicolumn{4}{|c|}{ 1.5 Person stay with } \\
\hline Father & 56 & 18.67 & 3 \\
\hline Mother & 93 & 31.00 & 1 \\
\hline Grandfather & 36 & 12.00 & 4 \\
\hline Grandmother & 66 & 22.00 & 2 \\
\hline Brother & 16 & 5.33 & 5 \\
\hline Sister & 9 & 3.00 & 7 \\
\hline Cousin & 9 & 3.00 & 7 \\
\hline Friend & 1 & 0.33 & 8 \\
\hline Others & 14 & 4.67 & 6 \\
\hline Total & 300 & $100 \%$ & \\
\hline
\end{tabular}

Age- Out of the three hundred (300) children, forty-seven (47) children belonged to the age of six years old; thirty - nine (39) children having the age of seven years old; forty (40) children were eight years old; fifty- five (55) 
children were nine years old; forty - eight under ten years old; and seventy - one (71) children belonged to 11 and above years old respectively.

Sex- One hundred forty - nine (149) out of the three hundred children (300) children were males while, there were one hundred fifty - one (151) female- respondents.

Grade Level- Out of the three hundred (300) respondents, seventy (70) of them were in grade six which mark the highest; while the grade five, grade two and grade three has forty-five (45) respondents which mark the lowest.

Number of Siblings- The highest number of siblings were one hundred twenty -two (122) who were under the bracket of below 2; hence, there were three (3) of them belong to 9-10 bracket and rank as the lowest;

Person stays with- Out of three hundred (300) children, ninety-three (93) of them were under the care of their mother which is the highest; while only one (1) only of them was staying with a friend which mark the lowest.

Teachers' assessment on the behavioral development of the pupil-respondents' living in a broken family. The first in rank was statement no. 1 "Achieves mutual understanding of and commitment to decisions" with the weighted mean of 3.08 or describe as frequently followed by item number 4 "Connects with people" with a weighted mean of 2.90 or frequently, while the lowest in rank was statement number 11 "Keeps views and ideas to self", with the weighted mean of 2.28 or describe as sometimes. Children enrolled in the elementary school of Ubay, Bohol, Philippines possessed a desirable attitude of a learner where commitment and relationship is observed in school.

Table 2: Teachers' Assessment on Behavioral Development of Pupil-Respondents Living in a Broken Family $\mathrm{N}=300$

\begin{tabular}{|c|c|c|c|}
\hline Statement & WM & VI & Rank \\
\hline 1. Achieves mutual understanding of and commitment to decisions & 3.08 & $\mathrm{~F}$ & 1 \\
\hline 2. Argues and threatens & 2.56 & $\mathrm{~F}$ & 13 \\
\hline 3. Commands respect and trust & 2.86 & $\mathrm{~F}$ & 3 \\
\hline 4. Connects with people & 2.90 & $\mathrm{~F}$ & 2 \\
\hline 5. Easily influenced by bad habits and traits & 2.73 & $\mathrm{~F}$ & 7 \\
\hline 6. Fearful of risks & 2.33 & $\mathrm{~S}$ & 19 \\
\hline 7. Insensitive and blunt & 2.29 & $\mathrm{~S}$ & 20 \\
\hline 8. Is overly independent & 2.80 & $\mathrm{~F}$ & 5 \\
\hline 9. Is reluctant to reach decisions & 2.52 & $\mathrm{~F}$ & 14 \\
\hline 10. Keeps an open mind & 2.74 & $\mathrm{~F}$ & 6 \\
\hline 11. Keeps views and ideas to self & 2.28 & $\mathrm{~S}$ & 21 \\
\hline 12. Listens at a thinking level & 2.63 & $\mathrm{~F}$ & 8 \\
\hline 13. Makes popular, rather than tough, decisions & 2.83 & $\mathrm{~F}$ & 4 \\
\hline 14. Reacts rather than initiates & 2.38 & $\mathrm{~S}$ & 17 \\
\hline 16. Seeks and gives facts; shares ideas & 2.47 & $\mathrm{~S}$ & 16 \\
\hline 17. Solicits ideas and opinions from others & 2.62 & $\mathrm{~F}$ & 9 \\
\hline 18. Manage emotion well & 2.57 & $\mathrm{~F}$ & 12 \\
\hline 19. Appreciates feedback & 2.61 & $\mathrm{~F}$ & 10 \\
\hline 21. Work independently on learning activities at home & 2.57 & $\mathrm{~F}$ & 12 \\
\hline Average Weighted Mean & 2.60 & $\mathrm{~F}$ & 11 \\
\hline & 2.51 & $\mathrm{~F}$ & 15 \\
\hline & 2.61 & $\mathrm{Frequently}$ \\
\hline
\end{tabular}

Legend:

Rating Scale Verbal Interpretation (VI)

Rating Scale Verbal Interpretation (VI)

3.25-4.00 Always (A)

$1.75-2.49$ Sometimes (S)

$2.50-3.24 \quad$ Frequently (F)

$1.00-1.74 \quad$ Not at All (NA)

Teachers' assessment on the academic success of the pupils' living in a broken family. The highest in rank was statement 3 "Attend to class regularly" with the weighted mean of 2.93 or describe as agree, followed by statement number 7 "observes punctuality and attend to class regularly" with a weighted mean of 2.81 or Agree, 
meanwhile the statement number 11 "Able to achieve in honor roll", was the lowest weighted mean of 2.32 or describe as disagree. The pupil-respondents were responsibly managed to attend classes regularly. These pupils tried to overcome adversity and fulfill goals in life even they have experienced the said condition.

Table 3: Teachers' Assessment on the Academic Success of Pupil-Respondents Living in a Broken Family N= 300

\begin{tabular}{|c|c|c|c|}
\hline Statement & WM & VI & Rank \\
\hline 1. perform poorly on home assignment & 2.72 & F & 4 \\
\hline 2. got low score on test/ quizzes & 2.64 & F & 7 \\
\hline 3. attend to class regularly & 2.93 & F & 1 \\
\hline 4. perform group assignment well & 2.66 & F & 6 \\
\hline 5. participates in the class activity & 2.77 & F & 3 \\
\hline 6. cannot cope up with the lessons quickly & 2.50 & F & 12 \\
\hline 7. observes punctuality and attend to class regularly & 2.81 & F & 2 \\
\hline 8. does indiscipline affect the performance in school & 2.71 & F & 5 \\
\hline 9. being optimistic most of the time & 2.59 & F & 9 \\
\hline 10. make things organized and orderly & 2.47 & S & 13 \\
\hline 11. able to achieve in honor roll & 2.32 & S & 15 \\
\hline 12. have difficulty in comprehending lessons & 2.53 & F & 11 \\
\hline 13. have a positive attitude towards self & 2.61 & F & 8 \\
\hline 14. rarely passed the examination & 2.47 & S & 14 \\
\hline 15. never give up on task in school & 2.56 & F & 10 \\
\hline Average Weighted Mean & 2.62 & Frequently \\
\hline
\end{tabular}

Legend:

Rating Scale Verbal Interpretation (VI)

$3.25-4.00 \quad$ Always (A)

Rating Scale Verbal Interpretation (VI)

$2.50-3.24$

Frequently (F)

$1.75-2.49$ Sometimes (S)

$1.00-1.74 \quad$ Not at All (NA)

Relationship between the profile and behavioral development of the pupil-respondents living in a broken family. The result shown that there is no significant relationship between the behavioral development and profile of the pupil-respondents living in a broken family in terms of age, sex, grade level, number of siblings, and persons stay with since the corresponding significant values of $0.135,0.408,0.127,0.538$, and 0.556 are greater than 0.05 level of significance. Thus, this study accepts the null hypothesis. This implies that the respondents' age, sex, grade level, number of siblings, and persons stay with did not vary to their behavioral development, however the pupilrespondents were doing the things expected from them such as mutual understanding and commitment, and builds attachment with people especially in school.

Table 4: Relationship Between the Profile and Behavioral Development of the Pupil-Respondents Living in a Broken Family N = 300

\begin{tabular}{|c|c|c|c|}
\hline Profile & Sig. & Interpretation & Decision \\
\hline Age & 0.135 & Not Significant & Do Not Reject Ho \\
\hline Sex & 0.408 & Not Significant & Do Not Reject Ho \\
\hline Grade Level & 0.127 & Not Significant & Do Not Reject Ho \\
\hline Number of Siblings & 0.538 & Not Significant & Do Not Reject Ho \\
\hline Person Stay With & 0.556 & Not Significant & Do Not Reject Ho \\
\hline
\end{tabular}

Relationship between behavioral development and academic success of the pupil-respondents living in a broken family. The result revealed that there was a significant relationship between the behavioral development and academic success of the pupil-respondents living in a broken family since the computed correlation value of 0.154 with a significant value of 0.008 is lesser than 0.05 level of significance. Thus, the null hypothesis was rejected. This denotes that academic success of the pupils depends on their behavior development. Being with a broken family is 
not structurally intact, as a result of divorce, separation, death of one of parent and illegitimacy but they have an equal opportunity and chance to achieve success in school depending on how much work they will perform on it.

Table 5: Relationship Between Behavioral Development and Academic Success of the Pupil-Respondents Living in a Broken Family N = 300

\begin{tabular}{|c|c|c|c|c|}
\hline Behavioral Development and .. & r & Sig. & Interpretation & Decision \\
\hline Academic Success & 0.154 & 0.008 & Significant & Reject Ho \\
\hline
\end{tabular}

\section{CONCLUSIONS AND RECOMMENDATIONS}

\subsection{CONCLUSIONS}

It was found out that age, sex, grade level, number of siblings, and person stays with has no direct influence to the pupils' behavioral development, and however, academic success of the pupils depends on their behavior development. Therefore, it was concluded that the attitude and behavior of the learner affects academic success.

\subsection{RECOMMENDATIONS}

Based from the results of this study, the researchers came-up with the following recommendations. There should be an action plan implementation in school in order to help pupils under broken family achieve academic success; a peer facilitating group, team building, trainings and symposia should be included in the school guidance program to cater the behavioral and academic needs of the pupils; and the school should create peer facilitating group spearheaded by a guidance counselor/ adviser to have a regular monitoring and assistance for pupils with special educational needs.

\section{SOURCES OF FUNDING}

This research received no specific grant from any funding agency in the public, commercial, or not-for-profit sectors.

\section{CONFLICT OF INTEREST}

The author have declared that no competing interests exist.

\section{ACKNOWLEDGMENT}

He full support of the Department of Education especially the Anoling National High School, and to the Bohol Island State University- Candijay Campus, Cogtong, Candijay, Bohol, Philippines.

\section{REFERENCES}

[1] Ekanem, T. F. (2004). The school as a substitute home in Q. I. Obinaju (Ed), theory and practice in early childhood education. Calabar; Nigeria, BON Ltd.

[2] Adebule, S. O. (2004). Gender differences on a locally standardized anxiety rating scale in Mathematics for Nigerian secondary schools. Counselling and Applied Psychology, 1, 22 -29.

[3] Ghana Statistical Service: (August, 2005) Ghana population data analysis report, Vol.1 Accra,

[4] Agulana,G.G. (2000). Family structure and prevalence of behavioural problems among Nigerian adolescents. The Counselor 17(1), 154-161.

[5] Frazer, W.J. (2004). Family structure, parental practices and high school completion. American Sociology Review, (56), 309-320

[6] Gottfredson, M. \& Hirschi, T. (1990). A general theory of crime. Stanford, CA: Stanford University Press.

[7] Akinboye (2004). Development psychology. European Journal of Educational Vol.2, No.2, pp.10-23, 
[8] Maslow, A. H. (1970a). Motivation and personality. New York: Harper \& Row.

[9] Ainsworth, M. D. S., Blehar, M. C., Waters, E., \& Wall, S. (1978). Patterns of attachment: A psychological study of the strange situation. Citation

[10] Howes \& Ritchie, (2002). Early childhood education. Series Publisher: Teachers College Press

[11] Bowen, M. (2000). The study of the family. http://www.thebowencenter.org.

[12] Amato, P. R., \& Keith, B. (1991). Parental divorce and the well-being of children: A metaanalysis. Psychological Bulletin, 110, 26-46

[13] Amato, P.R. (2000). Children's' adjustment to divorce: Theories, hypotheses, and empirical support. Journal of Marriage and Family, 55, 23-38.

[14] Mclanahan \& Gary Sandefur. (1994). Growing up with a single parent: What hurts, what helps. Cambridge, MA: Harvard University Press. 